КАТЕГОРІАЛЬНИЙ АПАРАТ ДОСЛІДЖЕННЯ ВПЛИВУ ГРОМАДСЬКИХ ОРГАНІЗАЦІЙ НА ЗАБЕЗПЕЧЕННЯ ЯКОСТІ ВИЩОЇ ОСВІТИ

\title{
CATEGORICAL APPARATUS FOR RESEARCHING THE IMPACT OF NGOS ON HIGHER EDUCATION QUALITY
}

Аналіз закордонної та вітчизняної історіографрії засвідчує актуальність дослідження впливу громадських організацій на забезпечення якості вищої освіти. У статmі висвітлено опис міжнародних законодавчих актів, які надають громадським організаціям широкі повноваження як стейкхолдерам освітнього процесу та розширюють їх функціональні можливості у сфрері моніторингу та перевірки якості освітніх послуг. у статті з'ясовано, що термін «громадська організація» в національному законодавстві розглядається через «громадські об'єднання», до яких належать добровільне об'єднання фрізичних осіб та/або юридичних осіб приватного права для здійснення та захисту своїх інтересів. Національна інтерпретація ореномена «громадської організації» та ознаки «громадської організації», надані у відповідному Законі, відповідають вимогам, наданим «Communication from the Commission to the Council, the European parliament and the economic and social committee participation of non-state actors in EC development policy»s.

Описано підходи до типологізації громадських організацій, які розроблені в міжнародних класифрікаторах Всесвітньої асоціації неурядових організацій (WANGO) та Міжнародної класифрікації неприбуткового сектору (ICNPO), розроблені університетом Дж. Гопкінса та прийняті Організачією Об'єднаних Націй як стандарти для класифрікації неприбуткових організацій. В обох системах, канадській та американській, є спеціальні групи громадських організачії, які є дотичними до ссрери освіти, вищої освіти та забезпечення якості віщоі освіти. Проаналізовано підходи до визначення та типологізачії «громадських організації», які розроблені у Стандарті Державного комітету статистики України за участю Інституту держави і права ім. B.M. Корецького НАН України, згідно з яким функціонують громадські об'єднання, які утворюються як громадські організації або громадські спілки. Зроблено висновок про необхідність оновлення методологічних підходів національного Стандарту з використанням міжнародного досвіду задля організації кількісного аналізу діяльності громадських організацій відповідного типу. На основі існуючих підходів до визначення «громадська організація» та принципів WANGO ma ICNP запропоновано використання термінів «громадська освітянська організація» та «громадські освітянські організації, які діють у сорері вищої освіти» для позначення діяльності.

Ключові слова: громадська організачія, неприбуткова організація, громадське об'єднання, вища освіта, якість вищої освіти, громадська освітянська організація, класифікатор, типологізація.

The analysis of foreign and domestic historiography confirms the relevance of research of the impact made by the public organizations on the quality assurance of higher education. The article describes the international legislation that provides non-governmental organizations with broad powers as stakeholders of the educational process and enhances their capacity to monitor and verify the quality of educational services. The article clarifies that the term "non-governmental organization" in national law is considered through "civil organization/association", which includes the voluntary association of individuals and/or legal entities of private law to exercise and protect their interests. The national interpretation of the phenomenon of "non-governmental organization" and the features of "civil organization/ association" provided in the relevant Law meet the requirements provided by "Communication from the Commission to the Council, the European Parliament and the economic and social committee participation in non-state actors in EC development policy".

Approaches to typology of non-governmental organizations developed by the World Classification of Non-Governmental Organizations (WANGO) and International Non-Profit Classification (ICNPO), developed by Johns Hopkins University and adopted by the United Nations as non-governmental classification standards, are described in the paper. In both the Canadian and American systems, there are specialized groups of NGOs involved in education, higher education and quality assurance in higher education. Approaches to the definition and classification of "non-governmental organizations", which were developed in the Standard of the State Committee of Statistics of Ukraine with the participation of the Institute of State and Law named after V.M. Koretskiy, NAS of Ukraine, according to which public associations are formed as public organizations or public associations. It is concluded that the methodological approaches of the National Standard need to be updated with the use of international experience in order to organize quantitative analysis of the activities of the non-governmental organizations of the relevant type. On the basis of existing approaches to the definition of "civil organization/association" and the principles of WANGO and ICNP, the terms "educational organization" and "higher educational organizations" are proposed to be used. Key words: civil organization, non-governmental organization, civil organization, public association, higher education, quality of higher education, educational organization, classifier, classification.
Постановка проблеми у загальному вигляді. Сучасна держава фрункціонує та трансформується від впливом глобалізації та регіоналізації. Гуманітарний вимір діяльності держави якісно транс- формується, допускаючи до участі в контролі та координації розподілу публічних благ нових акторів, наприклад, вказана тенденція проявляє себе у сорері надання вищої освіти. 
Вища освіта $є$ специфічним різновидом публічного блага, який має велике значення для ефективності фрункціонування держави як системи, адже вища освіта виступає ретранслятором знань, вмінь, норм поведінки, цінностей, які формують майбутнього громадянина та спеціаліста.

Одним із найважливіших аспектів функціонування вищої освіти є проблема забезпечення якості вищої освіти. У пострадянських країнах система оцінки якості вищої освіти відбувалася державними інститутами (міністерства, спеціалізовані державні агентства тощо), оцінка якості мала «зовнішньоінституціональний» характер. Але трансорормація держави як регулятора соціуму надає можливості використання інших «зовнішньоінституціональних» інструментів для оцінки якості освітніх послуг, а саме: громадських організацій, які в умовах трансформації монополії держави на здійснення фрункцій в області управління освітою поступово стають повноправними стейкхолдерами фрункціонування зазначеного соціального інституту. За визначенням «Стандартів і рекомендацій щодо забезпечення якості в Європейському просторі вищої освіти (ESG)» цей термін означає: «Стейкхолдери - це учасники (суб'єкти) у межах закладу, включаючи студентів і персонал, а також зовнішні стейкхолдери, такі як працедавці та зовнішні партнери закладу» [22, с. 12].

Враховуючи взаємозумовленість впливу громадських організацій на систему вищої освіти та якість освітніх послуг, ще у 1998 р. на порядку денному конференції UNESCO «World Conference on Higher Education» (1998) було розглянуто питання про щільнішу взаємодію соціуму та системи вищої освіти та прийнято документ «Higher Education in the Twenty-first Century. Vision and Action» [11], в якому перелічено основні місії вищої освіти, серед яких «сприяння стійкому розвитку та вдосконалення суспільства взагалі» (mission to contribute to the sustainable development and improvement of society as a whole) [11].

У Доповіді «Bologna Process Implementation report: the European Higher Education in 2018» зазначено, що в Європейському просторі вищої освіти природа забезпечення якості основана на засадах розподіленої відповідальності з спеціалізованими агентствами та органами держави. Агентствами, які можуть брати участь у забезпеченні якості вищої освіти, Є акредитовані при European Quality Assurance Register (EQAR). Згідно з даними Болонського звіту 2018 р. в межах Європейського простору вищої освіти спостерігається зростання кількості агентств, відповідальних за забезпечення якості, але частина з них не зареєстрована в Європейському реєстрі забезпечення якості вищої освіти. Відповідно до ч. 1 Статуту European Quality Assurance Register партнерами організації можуть бути організації, які діють неза- лежно від органів державної влади та не мають комерційних інтересів (they operate independently, without interference in their decisions and operations from economic, governmental, institutional or other interests). Це дає змогу припустити, що юридична природа подібних організацій є близькою до природи «громадських організацій».

Виділення невирішених раніше частин загальної проблеми. Як бачимо, відносини між системою вищої освіти, державою та соціумом знаходяться у стані трансформації. Громадські організації як новий стейкхолдер освітнього процесу потребують додаткового аналізу 3 метою вироблення відповідного категоріально-понятійного апарату, якій дасть змогу відокремити риси громадської організації, яка дотична до функціонування освіти та вищої освіти.

Аналіз останніх досліджень і публікацій. Дослідженню теоретико-методичних засад та трансорормацій системи вищої освіти присвячені наукові роботи вітчизняних та зарубіжних вчених, серед яких дослідження В. Андрущенка, О. Вашуленка, С. Калашнікової, В. Кременя, В. Лугового, В. Радкевича, Ж. Таланової та інші. Функціональні аспекти діяльності громадських організацій та їх взаємодія з іншими суб'єктами суспільних процесів розглядаються у роботах М. Банчука, М. Багмета, О. Віннікова, О. Зеленько, В. Горбатенка, В. Гури, А. Колодій, О. Корнієвського, І. Кресіної, Ф. Михальченка, Ф. Рудича, Г. Щедрової та інших.

Дослідники звертають увагу на взаємозв'язок закладів вищої освіти та соціальних ініціатив. Так, О. Оржель зазначає: «Університетам належить роль суспільних лідерів, здатних запропонувати рішення для розв'язання економічної кризи, пом'якшення напруги між соціоетнічними або соціокультурними групами, надати рецепти для психологічної реабілітації тощо» [23, с. 6]. Автор наводить інфрормацію, яка ілюструє залучення закладів вищої освіти а забезпечення соціальних інтересів та життя громади через різноманітні форми «соціально насиченого навчального плану (Socially Engaged Curriculum), який включав взаємодію студентів із громадою (наприклад, польові дослідження, громадські проекти тощо), залучення роботодавців, інших зовнішніх стейкхолдерів до оцінювання результатів навчання та інші підходи в межах Проекту «ESPRIT: Enhancing the Social Characteristics and Public Responsibility of Israeli Teaching through a HEI-Student Alliance», який реалізовувався консорціумом 5 європейських та 6 ізраїльських партнерів у рамках Програми TEMPUS» [23, с. 9].

C. Калашникова зазначає, що сучасні університети діють в умовах відкритості та партнерства на основі нової моделі управління вищою освітою (врядування), яка «включає багато рівнів і багато акторів (учасників); правила, процедури і меха- 
нізми їх взаємодії для досягнення спільних цілей» та «спричинює зміну ролі держави в управлінні вищою освітою (від регулятора до фрасилітатора) та делегування/перерозподіл ії владних повноважень серед нових акторів (учасників) процесу управління» [21, с. 9].

О. Панич вважає, що коло стейкхолдерів у забезпеченні якості вищої освіти у країні збільшилося, але й досі залишається невизначеною концепція незалежних агентств при Національному агентстві з забезпечення якості. Дослідниця вважає можливим використання досвіду Європейських організацій, які діють у сфері забезпечення якості освіти, а саме: «Модельними тут можна вважати Європейську асоціацію забезпечення якості вищої освіти (European Association for Quality Assurancein Higher Education, ENQA) та Раду з акредитації вищої освіти (Councilfor Higher Education Accreditation, CHEA). Відмінність між цими організаціями полягає у тому, що ENQA акредитує агенції країн Болонського процесу, серед яких $€$ національні агенції і незалежні (засновані недержавними об'єднаннями)» [19].

У вітчизняних дослідженнях вплив громадських організацій на функціонування вищої освіти розглядається фррагментарно. У довідковому виданні «Національного освітнього глосарія» розкривається сутність європейських організацій, які входять до Групи Є4, утворюючи групу основних консультативних членів із супроводу Болонського процесу. Але в «Національному освітньому глосарії» не включено опис фрункцій та повноважень зазначених організацій та статутних документів [18, с. 19]. Дослідниця Г. Клімова розглядає освітні громадські організації крізь призму забезпечення якості вищої освіти та європейський досвід у зазначеній царині, але в їі роботах не вивчається сутність Групи Є4 як специфічного типу громадських організацій, дотичних до сорери освіти [18].

Дослідниця О. Гостєва у роботі «Європейський досвід взаємодії органів державної влади та громадських організацій», аналізуючи особливості фрранцузьких, німецьких, британських та американських громадських організацій, вивчає європейський досвід взаємодії органів державної влади з громадськими організаціями. Погоджуємося $з$ тезою дослідниці щодо того, що «розвинені демократичні країни мають багаторічний досвід щодо взаємодії влади з громадськістю та використовують різноманітні її фрорми і методи» [13].

У зарубіжній історіографії проблема впливу громадських організацій як інституту громадянського суспільства на функціонування системи вищої освіти також активно вивчається. Класичною у вивченні взаємодії громадських організацій та вищої освіти є робота Ivar Bleiklie «The University, the State, and Civil Society» (1999), в якій дослідник наголошує на тенденції до демокра- тизації через зростання ролі недержавних акторів у забезпеченні якості навчання у вищій школі (...trends in democracy through increasing the role of non-state actors in education quality assurance) [1]. За нашими спостереженнями, саме із зазначеної роботи розпочинається вивчення взаємодії громадських організацій та вищої освіти.

Tony Gallagher у дослідженні «Promoting the Civic and Democratic Role of Higher Education: The Next Challenge for the EHEA?» обґрунтовує залучення закладів вищої освіти до нових форм взаємодії із суспільством та прагнення університетів ділитися знаннями, ресурсами та навичками 3 громадськістю (we are committed to sharing our knowledge, resources and skills with the public, and to listening to and learning from the expertise and insight of the different communities with which we engage) [5, c. 339].

Як бачимо, проблематика взаємодії громадських організацій та системи вищої освіти як елементів громадянського суспільства $€$ цікавою для вивчення, хоча специфікою вказаної проблеми є відсутність цілісного категоріально-понятійного апарату для вивчення.

Мета статті. 3 огляду на постановку проблеми та аналіз наукової літератури, метою статті $€$ аналіз теоретико-методологічних підходів до визначення громадських організацій, дотичних до сектору освіти та вищої освіти, та розробка первинного категоріально-понятійного апарату для подальшого вивчення проблеми.

Виклад основного матеріалу. Нині функціонує розвинута система міжнародних законодавчих актів, яка дає змогу громадським організаціям впливати на функціонування вищої освіти та бути фрактором забезпечення ії̈ якості. Можливості громадських організацій як стейкхолдерів системи вищої освіти визначаються такими нормативними актами.

У Болонській декларації від 19 липня 1999 р. за громадськими організаціями було зафіксовано статус стейкхолдера освітнього процесу: «Для зміцнення європейської сорери вищої освіти політика міжурядового співробітництва спрямовується на залучення європейських неурядових організацій, що фрункціонують у сорері вищої освіти».

У Бергенському комюніке 2005 р. акцентовано на «тому, що важливу роль у реалізації Болонського процесу відіграють партнерські організації, які «представляють бізнес та соціальних партнерів», а також на внеску, зробленому «міжнародними інституціями та організаціями, які є партнерами процесу» [9].

Цим документом надано широкі повноваження громадським організаціям у сорері забезпечення якості вищої освіти. Прикладами таких громадських організацій $є$ такі: European Association for Quality Assurance in Higher Education - пропонує 
Стандарти і рекомендації щодо забезпечення якості (ESG); громадські організації European Association of Universities та European Student Information Bureau - надають доповіді щодо моніторингу Болонського прогресу, як це визначено II Частиною Комюніке [9].

Лондонське комюніке 2007 р. закріпило за певною категорією громадських організацій фрункцію забезпечення якості вищої освіти. Ці громадські організації становлять Групу Є4 (E4 Group) та проводять «щорічні Європейські фроруми із забезпечення якості, а також сприяють обміну позитивним досвідом у забезпеченні покращення якості в Європейському просторі вищої освіти і надалі» [7]

Найважливішим документом, який регламентує участь громадських організацій у функціонуванні системи вищої освіти та забезпеченні іï якості, $€$ «Standards and Guidelines for Quality Assurance in the European Higher Education Area (ESG)», у ч. 3 п. 3.3 якого діяльність громадських організацій у забезпеченні якості вищої освіти легалізовано: «Організаційна незалежність засвідчена в офріційних документах (наприклад, урядових нормативних документах, законодавчих актах або статуті організації), що визначають незалежність роботи агентства від третіх сторін, таких як заклади вищої освіти, уряди та інші організації стейкхолдерів» [22, с. 22].

В Єреванському комюніке 2015 р. йдеться про готовність країн, які підписали Болонську декларацію, співпрацювати на основі «відкритого діалогу, спільних цілей і загальних зобов'язань». У документі зазначено «необхідність переосмислення (renew) первинної візії ЕНЕA. Починається цей процес із переосмислення місії вищої освіти, яка має сприяти «створенню інклюзивних суспільств, заснованих на демократичних цінностях і правах людини», що надає суспільству можливість брати участь в фрункціонуванні вищої освіти в межах, дозволених законом організаційних фрорм, які зафріксовано в відповідних національних законодавствах. До таких фрорм належать, насамперед, громадські організації.

У Паризькому комюніке 2018 р. зазначено важливу роль громадських організацій як стейкхолдерів освітнього процесу: «Ми визнаємо, що ресрорми, скеровані Болонським процесом, вимагають як успішної реалізації, так і повної відповідальності за всі наші узгоджені цілі та зобов'язання в усьому ЄПВО. Виконання наших зобов'язань залежить від узгоджених зусиль національних політиків, державної влади, інституцій, працівників, студентів та інших стейкхолдерів, а також координації на рівні ЄПВО» [8].

Отже, 3 точки зору системи міжнародного права вплив громадських організацій на вищу освіту регламентується низкою загальноприйнятих міжнародних угод та домовленостей. В Укра- їні також існують нормативно-правові акти, якими регламентується діяльність різних стейкхолдерів у сорері вищої освіти. Базовим документом у цій сорері, в якому наданий вітчизняний погляд на сутність громадських організацій та принципи їх функціонування, є Закон України «Про громадські об'єднання» [16]. Для дослідження вказаного терміна скористуємося визначенням, прописаним у ст. 1 вказаного Закону: «Громадське об'єднання за організаційно-правовою фрормою утворюється як громадська організація або громадська спілка.

Громадська організація - це громадське об'єднання, засновниками та членами (учасниками) якого $€$ фрізичні особи» [16].

Термін «громадське об'єднання» розуміємо як «добровільне об'єднання фрізичних осіб та/або юридичних осіб приватного права для здійснення та захисту прав і свобод, задоволення суспільних, зокрема економічних, соціальних, культурних, екологічних та інших інтересів» [24, с. 232]. Зазначена інтерпретація терміна «громадська організація» узгоджується із визначенням, наданим у «Communication from the Commission to the Council, the European parliament and the economic and social committee participation of non-state actors in EC development policy» (2002) [2]. Згідно із вказаним документом до основних характеристик громадських організацій належать такі:

- недержавні актори (non-state actor);

- незалежність від органів державної влади (independent of the state);

- прибуткові або неприбуткові (profit or nonprofit-making organisations);

- низова ініціатива (created voluntarily by citizens);

- реалізація інтересів у певній сорері (their aim being to promote an issue or an interest, either general or specific) [2].

Можливості залучення громадських об'єднань до фрункціонування системи вищої освіти регламентуються не лише міжнародними документами. Прямими наслідками імплементації положень міжнародних документів стали положення Закону України «Про вищу освіту» [15]. По-перше, цим Законом визначено можливість різних стейкхолдерів брати участь в управлінні вищою освітою. Так, у Розділі IV ч. 2 Ст. 12 визначено, що: «Кабінет Міністрів України через систему органів виконавчої влади<...>забезпечує широку участь незалежних експертів і представників громадськості, роботодавців та осіб, які навчаються у закладах вищої освіти, у підготовці та прийнятті проектів нормативно-правових актів та інших рішень, що стосуються регулювання взаємодії складових системи вищої освіти та її функціонування в цілому» [15].

Громадські організації мають вплив на такий елемент вищої освіти, як забезпечення якості. Вказане право частково зафріксоване у ст. 23: 
«Незалежна установа оцінювання та забезпечення якості вищої освіти - це недержавна організація (установа, агенція, бюро тощо), акредитована Національним агентством із забезпечення якості вищої освіти, що здійснює оцінювання освітньої програми, результатів навчання та/або закладів вищої освіти (їхніх структурних підрозділів) 3 метою вироблення рекомендацій і надання допомоги закладам вищої освіти в організації системи забезпечення якості вищої освіти та внесення пропозицій Національному агентству із забезпечення якості вищої освіти щодо акредитації освітньої програми» [15].

Для громадських об'єднань, які претендують впливати на процес забезпечення якості вищої освіти, є можливості співпраці з авторитетними міжнародними організаціями, наприклад, ст. 23 вказує на можливість діалогу 3 європейськими партнерами у сорері обміну досвідом та впровадження європейських стандартів: «Незалежні установи оцінювання та забезпечення якості вищої освіти можуть співпрацювати 3 Європейською асоціацією із забезпечення якості вищої освіти». Незалежні установи оцінювання та забезпечення якості вищої освіти також мають право «видавати закладам вищої освіти власні сертифрікати про оцінку освітньої програми та/або систем забезпечення якості вищої освіти» [15].

Незалежні установи оцінювання та забезпечення якості вищої освіти мають окремі ознаки громадських об'єднань, прописані у ст. 1 Закону «Про громадські об'єднання» [16]:

- «громадське об'єднання - це добровільне об'єднання фрізичних осіб та/або юридичних осіб приватного права для здійснення та захисту прав і свобод, задоволення суспільних, зокрема економічних, соціальних, культурних, екологічних та інших інтересів;

- громадське об'єднання за організаційно-правовою фрормою утворюється як громадська організація або громадська спілка».

Зазначимо, що в юридичній літературі поняття «недержавні організації» розглядається як тотожне «громадській організації», адже чітке юридичне тлумачення терміна «недержавна організація» в українському законодавстві відсутнє, натомість поняття «громадська організація» розглядається як «організаційно-правова фрорма» громадського об'єднання. Наразі юридична природа «незалежних установ оцінювання та забезпечення якості вищої освіти» чітко не зафріксована ані в Законі «Про вищу освіту» [15], ані у «Проекті Положення про акредитацію освітніх програм, за якими здійснюється підготовка здобувачів вищої освіти» [20], що надає підстави не зараховувати їх автоматично до різновиду юридичних осіб публічного права, а розглядати як юридичні особи приватного права, або простіше - громадські об'єднання, які створюються у фрормі громадської організації, поки інше не буде встановлено законодавством ${ }^{1}$.

Аналіз вітчизняної законодавчої бази, як бачимо, підтверджує той факт, що громадські організації є повноправним стейкхолдером освітнього процесу та здійснюють вплив на забезпечення їі якості. Посилення ролі неурядових громадських організацій та тенденція до збільшення їх кількості, з одного боку, свідчать про підвищення активності громадян. Ефрективність фрункціонального ресурсу громадських організацій на локальному, національному та міжнародному рівнях ґрунтується на розумінні сутності, фрункцій та різновидів громадських організацій. Але виникає проблема класифрікації: які саме громадські організації вважати дотичними до сектору освіти та вищої освіти?

Розроблена велика кількість підходів до визначення сутності громадських організацій, але немає єдиного термінологічного та методологічного апарату для глибинного дослідження вказаного феномена. Для аналізу діяльності громадських організацій вважаємо за потрібне звернутися до класифікації громадських організацій, які існують у міжнародних класифікаторах, розроблених міжнародними (глобальними) Асоціаціями громадських організацій. Існуючі підходи до класифрікації громадських організацій Всесвітньої асоціації неурядових організацій (WANGO) та Міжнародної класиорікації неприбуткового сектору (ICNPO), розроблені університетом Дж. Гопкінса та прийняті Організацією Об'єднаних Націй як стандарт для класифрікації неприбуткових організацій, можуть слугувати рамкою для дослідження діяльності громадських організацій у багатьох сорерах, зокрема й у сорері вищої освіти.

У вказаних класифікаторах вироблений споріднений погляд на сутність «громадської організації»: Всесвітня асоціація неурядових організацій (WANGO) та Міжнародна класифікація неприбуткового сектору (ICNPO) вважають за доцільне використання назви «неурядова організація», чия діяльність може бути лише профільно пов'язана 3 урядовими агентствами та інститутами, і яка працює на неприбутковій основі [6; 10]. «неурядова організація» може виконувати свої фрункції на національному, регіональному або місцевому рівнях або комбінувати зазначені рівні. Будь-які доходи (у вигляді грантів тощо) не використовуються на користь окремих членів організації.

Різні типи громадських організацій відповідно до сорери їхньої діяльності перелічені в довіднику WANGO, який налічує 6 великих розділів [10].

\footnotetext{
${ }^{1}$ Головна відмінність між юридичними особами публічного права та приватного права полягає в тому, що юридичні особи приватного права створюються на підставі установчих документів (статуту або засновницького договору, якщо інше не встановлено законом), а публічні - на підставі розпорядчого акту Президента України, органу державної влади, органу влади АРК або органу місцевого самоврядування.
} 
Критерієм поділу є сорера діяльності організацій: громадські організації з прав людини; громадські організації з освіти; екологічні громадські організації; ґендерні громадські організації; дитячі громадські організації; молодіжні громадські організації.

Всесвітня асоціація неурядових організацій WANGO об'єднує громадські організації у всьому світі, виконуючи роль «парасолькової організації» [10]. Асоціація забезпечує механізм і підтримку, необхідну громадським організаціям для співпраці, партнерства та посилення своїх внесків для вирішення основних проблем людства, та розробляє спеціальний різновид нормативних актів, які застосовують лише громадські організації у процесі свого фрункціонування.

Відповідно до Міжнародної класифрікації неприбуткового сектору (The International Classification of Non-profit Organizations (ICNPO), розробленої університетом Дж. Гопкінса та прийнятої Організацією Об'єднаних Націй як стандарт для класифрікації неприбуткових організацій, методологічно вірним $€$ використання терміна «неприбуткова організація» 3 такими ознаками: інституціолізовані (мають статут, структуру, фріксований/нефріксований інститут членства, офріційну реєстрацію та здатні контролювати власну діяльність); неприбуткові (не створюються з метою отримання прибутку); інституційно відокремлені від уряду [6, с. 22]

Система ICNPO об'єднує громадські організації в 12 основних груп діяльності, включаючи категорію «некласифіковані»: культура та відпочинок; освіта та дослідження; здоров'я; соціальні послуги; довкілля; розвиток та житло; закон, адвокатура та політика; благодійність; міжнародні; релігійні; ділові та профресійні об'єднання, спілки; некласифріковані. Зазначені 12 типів організацій поділяються на 24 підгрупи. Кожна група має свої особливості, так, наприклад, група 9 «Міжнародні організації» об'єднує діяльність угруповань, зайнятих у таких сорерах, як культурні/навчальні обміни, зі сприяння соціальному та економічному розвитку, ліквідації наслідків стихійних лих, допомоги 3 прав людини. Вказаний класифікатор суперечить загальноприйнятому розподілу організацій за територіальною ознакою, в межах якого організація будь-якого фрункціонального спрямування стає міжнародною, якщо об'єднує представників кількох країн, організації з кількох країн та проводить заходи на території кількох країн [6, с. 26-32].

Як бачимо, обидва класифікатори використовують, насамперед, функціональний підхід, розподіляючи громадські організації за сорерами діяльності, а не за територіальною ознакою. При цьому обидва «парасолькові об'єднання» використовують єдиний підхід до визначення сутності громадських організацій: неприбутковість та відокремленість від держави. Існують певні об'єктивні складнощі, пов'язані 3 перекладом терміна: так, ICNPO використовує поняття «nonprofit organization», a WANGO - «non-governmental organization» при позначенні громадської діяльності, хоча в описах терміна поняття про відокремленість від державних органів та неприбутковість діяльності вказується в довідниках обох міжнародних асоціацій.

На території України діє власний класифрікатор, розробником якого є Державний комітет статистики України за участю Інституту держави і права ім. В.М. Корецького НАН України, згідно з яким функціонують громадські об'єднання, які утворюються як громадські організації або громадські спілки [14]. Своєю чергою, громадські організації визначаються через громадські об'єднання, засновниками та членами (учасниками) якого $€$ фрізичні особи.

Класифрікатор ділить організації на політичні партії, громадські організації, громадські спілки, спілки об'єднань громадян, релігійні організації, профрспілки, благодійні організації, організації роботодавців, ОСББ та органи самоорганізації населення [14, с. 8]. Як бачимо, вітчизняний класифрікатор, насамперед, орієнтується на організаційно-правову складову частину, а не на функціональний компонент, відповідно, громадські організації, дотичні до освіти чи до вищої освіти, відсутні в переліку.

Отже, з точки зору методології існують розбіжності між міжнародними та українськими класифрікаторами, що не дає змоги здійснювати кількісний аналіз певних типів громадських організацій та відслідковувати динаміку показників їх діяльності. Відсутність єдиного класисрікатора унеможливлює операцію з порівняння громадських організацій у різних країнах світу, що актуалізує для дослідників необхідність бути уважними в описі діяльності організацій та їх типологізації.

Висновки. На наш погляд, цілком можливим $€$ додавання в чинний вітчизняний класифрікатор категорії «інші організації» та потенційно можна запровадити категорію «освітянська організація». Таке фрормулювання дасть змогу охопити діяльність організацій, які дотичні до сфери освіти та виконують різні функції, тобто така дефініція не зводить розуміння організації як такої, що надає освіту, а передбачає широке коло питань, дотичних до неї. Категорію «громадська освітянська організація» можна охарактеризувати як «тип громадської організації, яка здійснює діяльність у сорері освіти, спрямовану на захист та реалізацію інтересів членів вказаної організації та/або загальносуспільних інтересів у сорері освіти» [12, с. 152]. Використовуючи методологічні розроблення Всесвітньої асоціації неурядових організацій, «громадські освітянські організації» можна представити у вигляді кількох секторів, серед яких можуть бути «громадські освітянські організа- 
ції, які діють у сорері вищої освіти». Під ними ми пропонуємо розуміти різновид «громадської освітянської організації, чия діяльність дотична до вищої освіти та спрямована на захист та реалізацію інтересів членів зазначеної організації ma/ чи загальносуспільних інтересів у сорері вищої освіти» [12, с. 152]. Сорера діяльності громадських освітянських організацій включає моніторинг, розвиток та аудит якості вищої освіти. Цим пояснюється змога виокремити різні підтипи громадських освітянських організацій, які діють у сорері вищої освіти відповідно до свого функціонального призначення. Перелік фрункцій громадських організацій у сорері вищої освіти є достатньо великим, що робить перспективними дослідження, спрямовані на розробку інструментарію для подальшого вивчення впливу громадських організацій на фрункціонування вищої освіти.

\section{БІБЛІОГРАФІЧНИЙ СПИСОК:}

1. Bleiklie Ivar The University, the State, and Civil Society. Education in Europe. Volume 24, 1999. Issue 4. URL: www.tandfonline.com/doi/ref/10.1080/0379 772990240404?scroll=topHigher. (дата звернення: 14.08.2019).

2. Communication from the Commission to the Council, the European parliament and the economic and social committee participation of non-state actors in EC development policy. URL: https://ec.europa.eu/europeaid/communication-commission-council-european-parliament-and-economic-and-social-committee-participation_en. (дата звернення: 16.08.2019).

3. EQAR Statutes. URL: https://www.eqar.eu/ assets/uploads/2018/04/EQAR_Statutes_ENv3_ 0-2017.pdf. (дата звернення: 19.08.2019).

4. European Commission/EACEA/Eurydice, 2018. The European Higher Education Area in 2018: Bologna Process Implementation Report. Luxembourg: Publications Office of the European Union. URL: https://eacea.ec.europa.eu/national-policies/eurydice/ sites/eurydice/files/bologna internet_chapter_4_0.pdf. (дата звернення: 19.08.2019).

5. Gallagher Tony «Promoting the Civic and Democratic Role of Higher Education: The Next Challenge for the EHEA?» The European Higher Education Area: The impact of the past and future policies. 2018. P. 335-344.

6. The Handbook on Non-Profit Institutions in the System of National Accounts. New-York : United Nations, 2003. 328 p.

7. London Communiqué Towards the European Higher Education Area: responding to challenges in a globalised world, London, 16-19 May, 2007. URL: http://www.ehea.info/Upload/document/ministerial_ declarations/2007_London_Communique_English_ 588697.pdf (дата звернення: 11.08.2019).

8. Paris Communiqué: EHEA Ministerial Conference, 2018. URL: https://mon.gov.ua/storage/app/ media/news/\%D0\%9D\%D0\%BE\%D0\%B2\%D0\%B 8\%D0\%BD\%D0\%B8/2018/06/06/12/paris-communiqueenua2018.pdf. (дата звернення: 11.08.2019).

9. The European Higher Education Area - Achieving the Goals Communiqué of the Conference of
European Ministers Responsible for Higher Education, Bergen, 19-20 May 2005. URL: http://www.ehea.info/ Upload/document/ministerial_declarations/ 2005_Bergen_Communique_english_580520.pdf (дата звернення: 11.08.2019).

10. The WANGO NGO Handbook. URL: http://www.wangohandbook.org/index.php?title=Main Page (дата звернення 01.09.2019)

11. World Conference on Higher Education: Higher Education in the Twenty-first Century. Vision and Action. UNESCO, Paris 5-9 October, 1998. URL: http://unesdoc.unesco.org/images/0011/001163/ 116345E.pdf (дата звернення: 10.08.2019).

12. Аналіз провідного вітчизняного та зарубіжного досвіду щодо оцінювання якості вищої освіти в умовах євроінтеграції: аналітичні матеріали (частина I) (препринт) / О. Воробйова, М. Дебич, І. Линьова, В. Луговий, О. Оржель, О. Слюсаренко, Ж. Таланова, К. Трима; за ред. В. Лугового, Ж. Таланової. Київ : Ін-т вищої освіти НАПН України, 2018. 172 с.

13. Гостєва О.М. Європейський досвід взаємодії органів державної влади та громадських організацій. Державне управління: удосконалення та розвиток. 2017. № 9. URL: http://www.dy.nayka.com. ua/?op=1\&z=1124 (дата звернення: 13.08.2019).

14. Державний класифрікатор України 002:2004 Класифікація організаційно-правових форм господарювання. Держспоживстандарт України, 2004. 24 с.

15. Закон України «Про вищу освіту». URL: http://zakon.rada.gov.ua/laws/show/1556-18(датазвернення: 12.08.2019).

16. Закон України «Про громадські об'єднання». URL: https://zakon.rada.gov.ua/laws/show/4572-17/ (дата звернення: 14.08.2019).

17. Клімова Г.П. Якість вищої освіти: європейський вимір. Вісник Національного університету «Юридична академія України імені Ярослава Мудрого». 2016. № 1 (28). URL: http://fil.nlu.edu.ua/ article/download/90231/85763 (дата звернення: 14.08.2019)

18. Національний освітній глосарій: вища освіта, 2014. 2 -е вид., перероб. і доп. /авт.-уклад. : В.М. Захарченко, С.А. Калашнікова, В.І. Луговий, А.В. Ставицький, Ю.М. Рашкевич, Ж.В. Таланова / За ред. В. Кременя. Київ : ТОВ «Видавничий дім «Плеяди», 2014. 100 c.

19. Панич О. Концептуальні засади створення незалежних установ оцінювання та забезпечення якості вищої освіти. URL: http://education-ua.org/ ua/articles/1344-kontseptualni-zasadi-stvorennyanezalezhnikh-ustanov-otsinyuvannya-tazabezpechennya-yakosti-vishchoji-osviti?fbclid= IwAR07OhEcdaX1KoriXRJzD_tqukfgVrKNczl1uYumfgt t1hniDFzawCXsu7Q (дата звернення: 20.08.2019).

20. Проект ПОЛОЖЕННЯ про акредитацію освітніх програм, за якими здійснюється підготовка здобувачів вищої освіти. URL: https://mon.gov.ua/ ua/news/mon-proponuye-dlya-gromadskogoobgovorennya-proekt-polozhennya-pro-akreditaciyuosvitnih-program-rozroblenij-nazyavo (дата звернення: 20.08.2019)

21. Розвиток інституційного потенціалу університетів у контексті глобального лідерства : колективна монографія / Авторський колектив: Є. Балджи, 
І. Драч, С. Калашнікова, О. Коваленко, С. Курбатов, Н. Невмержицька, О. Паламарчук, В. Рябченко, Л. Червона; за заг. ред. С. Калашнікової. Київ : Інститут вищої освіти НАПН України, 2017. 205 с.

22. Стандарти і рекомендації щодо забезпечення якості в Європейському просторі вищої освіти. Київ : Ленвіт, 2006. 35 с.
23. Університетська соціальна відповідальність у контексті університетського лідерства : навчальний посібник) / О. Оржель. Київ : ДП «НВЦ «Пріоритети», 2017. $40 \mathrm{c}$.

24. Юридична енциклопедія: у 6 т. / ред. кол. Ю.С. Шемшученко (відп. ред.) та ін. Київ : Укр. енциклоп. ім. М.П. Бажана, 1998. Т. 1: А - Г. 672 с. 